\title{
ENTREPRENEURIAL CHARACTER EDUCATION THROUGH THE SCHOOL CULTURE IN THE VOCATIONAL HIGH SCHOOLS
}

\author{
Nuryadin Eko Raharjo \\ Universitas Negeri Yogyakarta \\ nuryadin_er@uny.ac.id \\ Sukardi \\ Universitas Negeri Yogyakarta \\ sukardi@uny.ac.id \\ Husaini Usman \\ Universitas Negeri Yogyakarta \\ husaini_usman@uny.ac.id
}

\begin{abstract}
The study was to describe the implementation of the entrepreneurial character education through the school culture in the vocational high schools (VHSs). The method that the researcher made use in the study was the qualitative one. The study was conducted in the 2 Depok Public Vocational High School and the 2 Pengasih Public Vocational High School. The data source in the study was the school members, the documents, and the school cultures. The data was collected by means of observation, interview, and documentation. For the instruments, the researcher made use of the human instrument and the interview guideline. The data was analyzed by using the open coding, the axial coding and the selective coding. The findings in the research were as folows: the entrepreneurial character education by means of the school culture implementation in the VHSs had been included in the entrepreneurship culture through: $(1)$ the five artifacts in the verbal/conceptual dimension that might generate 17 dominant entrepreneurial characters; (2) the five artifacts in the action/behavioral dimension that might generate 8 dominant entrepreneurial characters; and (3) the four artifacts in the physical/material dimension that might generate seven dominant entrepreneurial characters.
\end{abstract}

Keywords: entrepreneurial character education, school culture, VHS 


\section{INTRODUCTION}

Vocational high school (VHS) as one of the institutions that generates the labors needs to pay attention to the competitive edge of the graduates in terms of comparative advantage, competitive advantage and cooperation capability. The comparative advantage refers to the the ability in producing goods/service with more cost-efficient manner. Then, the competitive advantage refers to the ability of the vocational high school graduates in pursuing the bargaining power. In order to achieve these advantages, the vocational high schools should empower their graduates in order that they will be able to compete in pursuing their employment or in opening their own employment. Through their capability in both pursuing and opening the employment, the vocational high school graduates are expected to be able to decrease the rate of unemployment in Indonesia which has still been high.

From the direction of national development on the national education in 2010-2014, the vision and the mission of the Directory of Vocational High School Education state that vocational high school graduates are demanded to be employment-independent and be business-independent. From the direction, it has been apparent that the focus of VHS development lies in the entrepreneurial development in order to produce VHS graduates who have entrepreneurial spirit and characteristics. Akbar (2009) argues that based on the results of a study conducted in the Harvard University one might conclude that the success of a person is not merely determined by the knowledge and the technical capability (the hard skill) that tend to develop the intelligence quotient (IQ); instead, the success of a person is determined more by the ability to manage himself or herself and the other people that has been found in the emotional quotient (EQ) and the spiritual quotient (SQ). The results of the study found that $20 \%$ of the success might only be determined by the hard skills and the remaining $80 \%$ of the success might be determined by the soft skills. The results of the study has been in accor-dance with the opinion of Goleman (2006, p. 44) that states that $80 \%$ of the success rate for a person in the community will be influenced by the emotional quotient and the rest $20 \%$ of the success rate will be influenced by the intelligence quotient.
The results of the study indicates that the entrepreneurial development in the VHS should be conducted comprehensively not only in the hard skills but also in the soft skills. The development of entrepreneurial soft skills will mostly be related to the development of entrepreneurial characters and cultures. Juridicially, the development has been in accordance with the Presidential Instruction Number 4 Year 1995 regarding the National Movement of Habituating and Culturalizing Entrepreneurship (Presiden Republik Indonesia, 1995). Through the national movement it has been expected that the entrepreneurial cultures will be the part of working ethics in the society, including the VHS members, in order to generate the reliable, tough and independent new entrepreneurs. Referring to the Presidential Instruction Number 4, the President of the Republic of Indonesia in his speech delivered in the 2010 National Summit has stated the importance of encouraging the entrepreneurial spirit and the educational metholodogy that develop the entrepreneurship more (Usman, 2010, p. 8). The entrepreneurial spirit is heavily related to the entrepreneurial characters. Thereby, in order to generate the VHS graduates that have entrepreneurial spirit the educational process will be heavily related to the entrepreneurial character education.

Philosophically, the concept of character education, including the entrepreneurial character education, has been manifested by $\mathrm{Ki}$ Hadjar Dewantara. In his educational concept, he argues that education is an effort to develop the manners (the power of internal-self and characters), the mind (the intellectual aspect) and the physic of the children. The components of the children's manner, mind and physic should not be separated in order to promote the children's life perfection. Thereby, it might be inferred that according to Ki Hadjar Dewantara character education has been a very important integral part in the education (Samani \& Hariyanto, 2011, p. 33).

Entrepreneurial characters are the characters of an entrepreneur that will be implemented in the entrepreneurial process. According to Dharma (2009, p. 14), the entrepreneurial characters are divided into three dimensions namely: moral knowing, moral feeling and moral action. Therefore, the entrepreneurial character education is an education that has been related to the fundamental values that de- 
velop one's personality in the entrepreneurial process and the education consists of moral knowing, moral feeling and moral action.

The implementation of the structural strategy has long ruled the reasoning pattern, the development of the working system and the improvement as having been done by the Department of National Education by rearranging multiple existing components, multiple regulations and curricular reorientations, multiple training programs and alike. According to the Department of National Education (Depdiknas, 2003 , p. 1), based on a long experience such structural strategy is not effective especially when the strategy encounters long-term needs that demand the improvement on the school quality. It has been explained further that based on multiple experiences and results of studies in the business world many experts have found that the school culture has been the best predictor in viewing the differences in the learning quality. Therefore, in order to implement the entrepreneurial education in all of educational degrees, including in VHS, the school culture should be the first priority.

The school culture might be used for pursuing the effective character education. Berkowitz (Elkind \& Sweet, 2004) explains that effective character education is not adding a program or set of programs to a school. Rather it is a transformation of the culture and life of the school. In other words, the implementation of character education, including the entrepreneurial character education in the VHS, will be more effective if the education is implemented by means of transformation in the school cultures and the school life rather than in the curriculum change by adding the learning materials of character education into the curriculum content. The learning effectiveness in the VHS by means of school culture is philosophically supported by one of the Prosser theories which states that vocational education will be effective in proportion as it trains the individual directly and specifically in the thinking habits and the manipulative habits required in the occupation itself (Prosser \& Quigley, 1950 , p. 220). Therefore, the habituation by means of school culture is believed to generate the effective vocational learning, including the development of entrepreneurial characters. The problem in such situation is: How is the implementation of entrepreneurial character education by means of school culture in the VHS?
In relation to the explanation, the objective of the study in general is to find the theory that has been related to the entrepreneurial character education by means of school culture in the VHS.

Then, the theoretical benefit of the study is to that the results of the study might support the theory of entrepreneurial education in the VHS especially that has heavily been related to the entrepreneurial characters by means of school culture benefit as the learning media. In addition, the practical benefit of the study is that the results of the study might be made as a matter of enrichment in the implementation of entrepreneurial education within the VHS.

According to Berkowitz \& Bier (2005), Nuh (2010), Ramly et al. (2010) Ramly (2010) and Samani \& Hariyanto (2011), entrepreneurial character education is an education that has been related to the fundamental values that establish one's personality within the entrepreneurial process. The entrepreneurial process consists of moral knowing, moral feeling and moral action that has been formed both by the hereditary influence and the environmental influence; then, the entrepreneurial process will be used as the foundation in the learning participants' paradigm, perspective, attitude and action as an entrepreneur.

Stolp \& Smith (1995), Schein (2004) and Rosseau (Sobirin, 2009) define the school culture as a conceptual design that contains the standards for taking decisions based on the fundamental assumptions and that will be used as the appropriate way of viewing, thinking and feeling in solving the problems that occur in the schools. Furthermore, they explain that the school culture is divided into three levels namely: (1) artefacts; (2) values and beliefs; and (3) basic assumptions. The artifacts serve as the outer layer of the school culture. Then, the values and beliefs serve as the middle layer of the school culture. Next, the basic assumptions serve as the inner layer of the school culture.

The artifacts in the school culture include all of the visible, heard and felt phenomena in the schools (Schein, 2004, p. 25). The construction of this level is formed through the physical and social environment. Sobirin (2009, p. 169) explains that artifacts have been the entry to understand the school culture for the external people and have been the form of cultural communication among the internal and 
the external people in the school. The artifacts have also been invisible element and have been easily observed by a person or a group of persons both from inside and outside the organization (visible and observable). Therefore, if the external people would like to understand the school culture then first of all the external people should understand the artifacts. Stolp \& Smith $(1995$, p. 36) propose that the level of school culture in the artifacts has been the easiest layer to be observed. The artifacts are the closest layer of school culture to the school atmosphere where people provide their perspective toward the schools. Thereby, the researcher would like to conclude that the artifacts of the school culture include all of the visible, heard and felt phenomena in the schools. The artifacts have been the very first aspect that will be observed in understanding the school culture.

In this layer, the artifacts, all people might view: (a) architecture of physical environment; (b) language; (c) technology and product; (d) creation; (e) dressing style; (f) behavior; (g) apparent emotion; (h) myth and organizational story; (i) published value; (j) apparent routine activity; (k) ceremony; (l) organizational flowchart; (m) formal description about how an organization works as having been written in the vision and the mission and alike (Schein, 2004, p. 25). In this case, the artifacts of physical buildings, including the physical buildings, might reflect the organizational cultures.

From the theory proposed by Hatch (1993), Stolp \& Smith (1995), Anonim, (2003), Schein (2004) and Sobirin (2009), the researcher might locate in details that in the artifacts there are three inter-related dimensions namely: (a) verbal/concep-tual dimension; (b) behavioral dimension; and (c) physical/material dimension. The elements that might be grouped into the verbal/concep-tual dimension are as follows: (a) schools' vision and mission; (b) curriculum; (c) schools' organizational structure; (d) schools' figures and achievement history; and (e) languages spoken in the schools. Then, the elements that might be grouped in the behavioral dimension are as follows: (a) teaching-learning activities; (b) routine habits/actvities; (c) rules, awards and punishments; (d) psychological and social supports; and (e) interactions with parents and community. Next, the elements that might be grouped into the physical/material dimension are as follows: (a) tools and facilities; (b) building form and layout; (c) motto and ornament; and (d) dressing/uniform manner.

\section{METHODS}

The study regarding the entrepreneurial character education by means of school culture in the VHS was conducted by means of qualitative method by selecting the school members of 2 Depok Public Vocational High School and 2 Pengasih Public Vocational High School as the samples. In accordance with the focus of the study and the selected approach, the data gathering instruments and techniques that the researcher were observation, interview and documentation.

The data gathering techniques that the researcher would make use of were as follows: observation, interview and documentation. Then, the instruments that the researcher would make use of in the study were the human instrument and the interview guideline. The data, then, would be analyzed by means of open coding, axial coding and selective coding.

\section{RESULTS AND DISCUSSIONS}

In order to educate the graduates to possess the competencies as an entrepreneur, both schools had implemented the entrepreneurial education through the teaching-learning activities both inside and outside the classrooms. The process of entrepreneurial education was heavily influenced by the school cultures, especially the ones in the entrepreneurship. Through the school cultures in the entrepreneurship, it had been expected that the vocational high school students would have the entrepreneurial characters both in order to meet the employment demand and to keep the pace with the higher education in accordance with the vocation.

In the study, the school cultures that had been referred to in order to implement the entrepreneurial character education in the VHS were the ones from the artifacts (consisting of three dimensions namely: verbal/conceptual dimension, behavioral dimension and physical/ material dimension) and the ones from values and beliefs. The three dimensions in the artifacts contained the values and the beliefs regarding the entrepreneurship, which finally 
would be crystalized in the deepest layer of school culture namely the basic assumptions.

The entrepreneurial character education by means of artifacts in the verbal/conceptual dimension would be performed in the following domain: (a) the schools' vision and mission that contained the entrepreneurial elements; (b) the schools' curriculum that was related to the entrepreneurship; (c) the schools' organizational structure that influenced the development of the school cultures; (d) the schools' history and figures that had attained the success in the entrepreneurship; and (e) the language that had been used on daily basis in the entrepreneurship.

The entrepreneurial character education by means of artifacts layer in the behavioral dimension would be performed in the following domain: (a) teaching-learning activities both that had been directly and indirectly related to the entrepreneurship; (b) routine activities/habits in the entrepreneurship that had been followed by the school members; (c) rules, awards and punishments that had been related to the school cultures in the entrepreneurship; (d) psychological and social supports toward the school members in the entrepreneurship; and (e) interaction with the parents and the community in the activities that had been related to the entrepreneurship.

On the other hand, the entrepreneurial character education by means of artifacts layer in the physical/material dimension would be performed in the following domain: (a) tools and facilities in the schools that would be used for the entrepreneurial activities; (b) forms and layouts of school buildings, especially the ones that would be used for the entrepreneurial activities; (c) mottos and decorations in the schools that were related to the entrepreneurship; and (d) school members' dresscodes/ uniforms, especially the ones that would be used in the entrepreneurship-related activities.

The results of this study had been in accordance with the theory of Hatch (1993), Stolp \& Smith (1995), Anonim (2003), Schein (2004), and Sobirin (2009), which explained that the school cultures consisted of three layers. The outer layer of the school cultures was the artifacts that consisted of three dimensions, namely: verbal/conceptual dimension, behavioral dimension and physical/material dimension. Then, the middle layer of the school cultures was the values and beliefs. The values in the school cultures constituted a guideline that had been believed as right and wrong. On the other hand, the beliefs in the school cultures constituted the attitudes in terms of how the school members should work in their schools. Next, the inner layer of the school cultures was the basic assumptions that contained indebatable directions and that should be obeyed by the school members; the basic assumptions included the directions in sensing and in thinking about every matter in the schools. In this research, the focus toward the school cultures in the entrepreneurship, which would be used for implementing the entrepreneurial character education.

The activities of integrating the entrepreneurial character education into the school cultures within the study were performed in the artifacts layer of the entrepreneurship that covered: (a) the verbal/conceptual dimension which were related to the entrepreneurial characters; (b) the behavioral dimension which were related to the entrepreneurial characters; and (c) the physical/material characters which were related to the entrepeneurial characters. The selection of the artifacts layer as the entrepreneurial character education medium was in accordance with the theory of Stolp \& Smith $(1995$, p. 36), which proposed that the school cultures in the artifacts layer has been the easiest aspect to observe.

The implementation of entrepreneurial character education-school cultures that was performed by integrating the entrepreneurial character education into the school cultures in the visible layer (the artifactas layer) finally would also influence the invisible layers (the values and beliefs and the basic assumptions). The implementation had been in accordance with the theory of Kotter \& Hesket (1997, p. 5 ), which explained that the changes on the artifacts layer would cause the changes in the deeper layers namely the values and beliefs and the basic assumptions. The theory had been in accordance as well with the condition in the 2 Depok Public Vocational High School and 2 Pengasih Public Vocational High School because the artifacts in both vocational high schools contained the entrepreneurial characters. On the other hand, the entrepreneurial characters were in the school cultures within the value and beliefs layer.

The interaction among the three layers of school cultures in the entrepreneurship 
within the study was a reciprocal one. According to Sobirin (2009, p. 154) the artifacts would generate the values and the beliefs in the school cultures; meanwhile, the existing values and beliefs would finally form the basic assumptions. Thereby, eventually the basic assumptions would be manifested into the values and the beliefs and would, therefore, be manifested as well in the artifacts of the school cultures.

From the study, the researcher found that all elements of the school cultures within the artifacts layer, in the verbal/conceptual dimension, the behavioral dimension and the physical/material dimension, contained the aspects that had been related to the entrepreneurial character education. However, the rate of association among the elements was not similar. There were some of the elements in the artifacts layer that might be heavily related to the entrepreneurial characters and, on the contrary, there were other elements that had less association to the entrepreneurial characters.

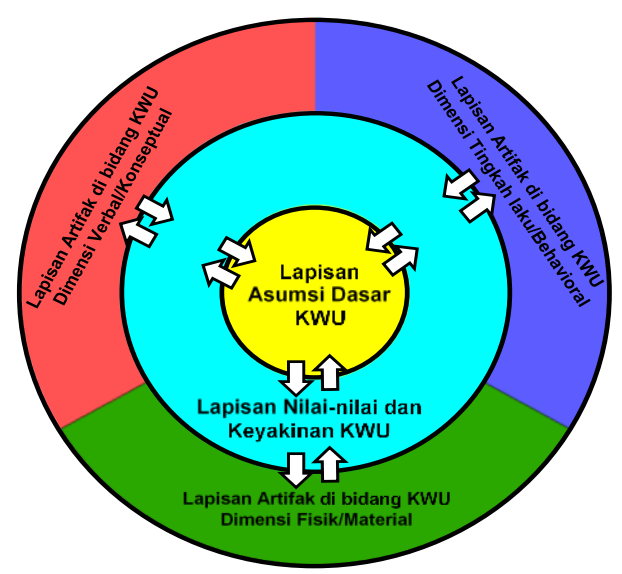

Figure 1. Integration of Entrepreneurial Character Education in the Entrepreneurial Character Education-School Cultures in the VHS

In relation to the role of Entrepreneurial Character Education-School Cultures in improving the school quality, the Entrepreneurial Character Education-School Cultures would be able to generate the VHS graduates that had entrepreneurial characteristics. The role had been in accordance with the theory of Stolp (1994), which proposed that from the results of a study a researcher might gather evidence that concluded that the school cultures had strong correlation to the improvement of achievement and motivation in the students' learning results.
In addition, the results of this study had also been in accordance with the theory of Stolp (1994), which stated that the school cultures in the entrepeneurship would influence the five aspects as follows: (1) the academic challenges in the entrepreneurship; (2) the academic achievements in the entrepreneurship; (3) the introduction or the understanding toward the students' achievements in the entrepreneurship; (4) the school community in the entrepreneurship; and (5) the students' perception toward the schools' objectives in the entrepreneurship. In addition, Stolp (1994) also concluded that the students would be more motivated in their learning if they had strong support from the school cultures.

The superiority of the educationals system that had been implemented by means of school cultures were a valid variable for measuring the school quality. However, the achievements of entrepreneurial character education that had been pursued through the school cultures were not as fast as those of the structural manner. Gunningham \& Gresso (Depdiknas, 2003, p. 5) implied that from the results of observation toward the structural improvement of school culture the schools had not been able to change the situations permanently. In the business domain, similar situation also occured as having been proposed by Kotter (Depdiknas, 2003, p. 5); he stated that success had been temporary in the short term if the changes would be pursued by means of restructurization. The changes of the school cultures would generate more permanent results in the long term. Thereby, it would be common if the school cultures would provide guidelines in assessing what would be important, what would be good, what would be right and how to achieve these aspects (Depdiknas, 2003, p. 5).

The results of this study has also been in accordance with the conclusions from the FGD activities. The factors that influenced the school cultures in the entrepreneurship were divided into three categories namely: influence from the figures, influence from the cultures and influence from the structures. The influence from the figures toward the school cultures consisted of the influence that had been exposed by: the school founders, the school owners, the principal management styles, the government figures and the community figures nearby the school. Then, the 
influence from the cultures toward the school cultures consisted of: (1) school characteristics; (2) existing school cultures; (3) school members' best practice; (4) school members' communication effectiveness; (5) students' family cultures; and (6) community cultures around the school. Next, the influence from the structures toward the school cultures covered: (1) the school's vision and mission; (2) the school's organizational structure; (3) the school's regulation; (4) the laws; and (5) the government policy.

In the study, it had been apparent that the school members also expected the support of the principals'roles toward the Entrepreneurial Character Education-School Cultures as having been implied in the theory of Want (2007, p. 160). He explained that the roles of schools' principals in developing the school cultures in the entrepreneurship were as follows. First, the principal should be a student of culture in which every school member should learn the school cultures including the ones in the entrepreneurship. Second, the principal should perform renewal process. Here, the principals should establish the school cultures as a renewal process. Third, the principals should perform communication. The principals should maintain communication among the school members in order to share ideas and resources. Fourth, the principals should perform inclusiveness. The principals should involve all of the school members in developing the school cultures within the entrepreneurship. Fifth, the principals should build trust. The principals should build trust among the school members, which emphasized that they were still safe in delivering their ideas. Sixth, the principals should perform accountability. The principals should be responsible toward the process of developing the school cultures in the entrepreneurship.

There were 18 entrepeneurial characters that the researcher found in the study and these characters were similar to the ones in the theoretical foundations; these characters were divided into three aspects namely: moral knowing, moral feeling and moral action. The entrepreneurial characters that belonged to the moral knowing were as follows: (a) creative; (b) innovative; (c) being able to perform future vision; and (d) being able to realistic decision taking. Then, the entrepreneurial characters that belonged to the moral feeling were as follows: (a) encouraged to take risk; (b) honest; (c) responsible; (d) never giving up; (e) having strong motivation to succeed; (f) curious; (g) committed; and (h) independent. Next, the entrepreneurial characters that belonged to the moral action were as follows: (a) hardworking; (b) having orientation toward action; (c) communicative; (d) cooperative; (e) showing leadership; and (f) disciplined.

From the results of data analysis, the entrepreneurial characters contained in the process of entrepreneurial characters education by means of school cultures (Entrepreneurial Character Education-School Cultures) on the artifacts layer within all dimensions (verbal/ conceptual dimension, behavioral dimension and physical/material dimension), the researcher had found the ranking for the entrepreneurial characters. If the researcher would like to differentiate the dominant and the indominant entrepreneurial characters within the Entrepreneurial Character Education-School Cultures, the researcher found the dominant characters in the Entrepreneurial Character Education-School Cultures as having been displayed in Table 1. The researcher would consider that the entrepreneurial characters would be dominant if the percentage were above $50 \%$.

Table 1. The Entrepreneurial Characters that were Dominant in the Entrepreneurial Character Education-School Cultures in the Verbal/Conceptual Dimension, the Behavioral Dimension and the Physical/Material Dimension

\begin{tabular}{llcc}
\hline No & $\begin{array}{l}\text { Dominant Entrepreneur } \\
\text { Character }\end{array}$ & $\begin{array}{c}\text { Percen- } \\
\text { tage }\end{array}$ & Aspect \\
\hline 1 & Creative & 79.34 & Moral knowing \\
2 & Realistic decision taking & 61.90 & Moral knowing \\
3 & Innovative & 52.95 & Moral knowing \\
4 & Responsible & 74.32 & Moral feeling \\
5 & Honest & 63.71 & Moral feeling \\
6 & Cooperative & 87.27 & Moral Action \\
7 & Hardworking & 72.28 & Moral Action \\
8 & Communicative & 67.64 & Moral Action \\
9 & Disciplined & 65.59 & Moral Action \\
\hline
\end{tabular}

From Table 1, it had been apparent as well that the dominant entrepreneurial characters $(>50 \%)$ in the school members' activities 
of 2 Depok Public Vocational High School and 2 Pengasuh Public Vocational High School on the aspect of moral knowing were as follows: creative, being able to perform realistic decision taking and innovative. Then, the dominant entrepreneurial characters in the school members' activities in the 2 Depok Public Vocational High School and 2 Pengasih Public Vocational High School on the moral feeling were honest and responsible. Then, the dominant entrepreneurial characters in the school members' activities in the 2 Depok Public Vocational High School and 2 Pengasuh Public Vocational High School on the moral action were as follows: cooperative, hardworking, communication and disciplined.

The above entrepreneurial characters were attained by analyzing the activities of the school cultures in the artifacts layer that covered all dimensions namely: the verbal/conceptual dimension, the behavioral dimension and the physical/material dimension. If the analysis would be performed to each dimension in the artifacts layer, definitely the researcher, then, would have different results. On the other hand, if the entrepreneurial characters in the process of entrepreneurial character education by means of school cultures (Entrepreneurial Character Education-School Cultures) would be analyzed based on the artifact layers in the verbal/conceptual dimension only (without any consideration toward the beha-vioral dimension and the physical/material dimension), then the researcher would find the ranking for 17 dominant entrepreneurial characters as having been displayed in Table 2 .

If the entrepreneurial characters in the process of entrepreneurial character education by means of school cultures (Entrepreneurial Character Education-School Cultures) would be analyzed based on the artifacts layer in the behavioral dimension only (without any consideration toward the verbal/conceptual dimension and the physical/material dimension), then the researcher would find the ranking toward the 8 dominant entrepreneurial characters as having been displayed in Table 3 .

Furthermore, if the entrepreneurial characters in the process of entrepreneurial character education by means of school cultures (Entrepreneurial Character Education-School Cul- tures) would be analyzed based on the physical/material dimension only (without any consideration toward the verbal/conceptual dimension and the behavioral dimension), then the researcher would find the ranking toward the 7 dominant entrepreneurial characters as having been displayed in Table 4 .

Table 2. The Entrepreneurial Characters that were Dominant in the

Entrepreneurial Character Education-School Cultures within the Verbal/Conceptual Dimension

\begin{tabular}{rlcc}
\hline No & $\begin{array}{l}\text { Dominant Entreprenur } \\
\text { Character }\end{array}$ & $\begin{array}{c}\text { Percen- } \\
\text { tage }\end{array}$ & Aspect \\
\hline 1 & Creative & 92.86 & Moral knowing \\
2 & Vision toward the future & 85.71 & Moral knowing \\
3 & Innovative & 78.57 & Moral knowing \\
4 & Realistic decision taking & 78.57 & Moral knowing \\
5 & Independent & 92.86 & Moral feeling \\
6 & Honest & 78.57 & Moral feeling \\
7 & Responsible & 78.57 & Moral feeling \\
8 & Committed & 78.57 & Moral feeling \\
9 & Encouraged risk-taking & 64.29 & Moral feeling \\
10 & Never giving up & 64.29 & Moral feeling \\
11 & Curious & 64.29 & Moral feeling \\
12 & Communicative & 92.86 & Moral action \\
13 & Cooperative & 92.86 & Moral action \\
14 & Hardworking & 78.57 & Moral action \\
15 & Performing leadership & 78.57 & Moral action \\
16 & Disciplined & 78.57 & Moral action \\
17 & Action-oriented & 64.29 & Moral action \\
\hline
\end{tabular}

Table 3. The Entrepreneurial Characters that were Dominant in the Entrepreneurial Character Education-School Cultures within the Behavioral Dimension

\begin{tabular}{clcc}
\hline No & $\begin{array}{l}\text { Dominant Entrepreneur } \\
\text { Character }\end{array}$ & $\begin{array}{c}\text { Percen- } \\
\text { tage }\end{array}$ & Aspek \\
\hline 1 & Creative & 78.63 & Moral knowing \\
2 & Realistic decision taking & 58.96 & Moral knowing \\
3 & Responsible & 76.00 & Moral knowing \\
4 & Honest & 65.04 & Moral knowing \\
5 & Cooperative & 88.78 & Moral action \\
6 & Hardworking & 70.86 & Moral action \\
7 & Communicative & 65.04 & Moral action \\
8 & Disciplined & 59.90 & Moral action \\
\hline
\end{tabular}


Table 4. The Entrepreneurial Characters that were Dominant in the

Entrepreneurial Character

Education-School Cultures within the Physical/Material Dimension

\begin{tabular}{llcc}
\hline \multirow{2}{*}{ No $\begin{array}{l}\text { Dominant } \\
\text { Entrepreneurial Character }\end{array}$} & $\begin{array}{c}\text { Percen- } \\
\text { tage }\end{array}$ & Aspect \\
\hline 1 Creative & 62.50 & Moral knowing \\
2 & Innovative & 62.50 & Moral knowing \\
3 & Realistic decision taking & 62.50 & Moral knowing \\
4 & Action-oriented & 100.00 & Moral action \\
5 & Disciplined & 100.00 & Moral action \\
6 Hardworking & 75.00 & Moral action \\
7 Cooperative & 62.50 & Moral action \\
\hline
\end{tabular}

From these tables, the researcher would like to conclude that the school cultures in the entrepreneurship within the 2 Depok Public Vocational High School and the 2 Pengasih Public Vocational High School in the verbal/ conceptual dimension that contained many matters with regards to the school concept/ planning covered: (a) the school's vision and mission; (b) the curriculum; (c) the school's organizational structure; (d) the figure and the history of success in the school; and (e) the language that would be used in the school; all of these aspects had contained many entrepreneurial characters. From the 18 entrepreneurial characters that had been found in the study, the researcher found that the verbal/conceptual dimension had contained 17 entrepreneurial characters which percentage had been over than $50 \%$ in the number of activities (the result excluded the strong motivation toward the achievements). Although the school cultures in the entrepreneurship within the verbal/conceptual dimension that were heavily related to the school planning had contained many multiple entrepeneurial characters, the school cultures in the entrepeneurship in the artifacts layer within the behavioral dimension that were related to the school members'activities had contained few entrepreneurial characteristics.

From the 18 entrepreneurial characters that the researcher found in the study, the behavioral dimension contained only 8 dominant entrepreneurial characters namely: (a) creative; (b) realistica decision taking; (c) responsible; (d) honest; (e) hardworking; (f) cooperative; (g) communicative; and (h) disciplined. Thereby, although the planning of entrepreneurial character education had contained the entrepreneurial elements, the implementation of the entrepreneurial character education on the daily basis (which included: (a) teaching-learning activities; (b) routine habits/activities; (c) rules, rewards and punishments; (d) psychological and social supports; and (e) interactions with parents and society) had not contained much of these characteristics. Based on the data presented above, it had been apparent that the implementation of entrepreneurial character education on the daily basis had not used much of the entrepreneurial characters and, as a result, the entrepreneurial school cultures lied in the artifacts layer on the physical/material dimension, which had been heavily related to the school facilities, had not been used much for the entrepreneurial activities.

Furthermore, from the 18 entrepreneurial characters found in the study the physical/material dimension contained only 7 dominant entrepreneurial characters namely: (a) creative; (b) innovative; (c) realistical decision taking; (d) action-oriented; (e) disciplined; (f) hardworking; and (g) cooperative. Thereby, the researcher might infer that the entrepreneurial school cultures lied in the artifacts layer on the physical/material dimension that had been heavily related to the facilities were as follows: (a) tools and facilities; (b); forms and layouts of buildings; (c) mottos and decorations; (d) dresscodes/uniforms; unfortunately, these characters had not been harnessed optimally in order to support the entrepreneurial character education by means of school cultures.

The improvement of entrepreneurial characters by means of school cultures lied in the artifacts layer on the behavioral dimension and the physical/material dimensions might be pursued by implementing the theory of Sathe (1985, p. 17), which emphasized the process of school members' communication. According to Sathe, the process of school cultures formation came from the basic assumptions that had been shared by the school members in multiple forms namely: (a) shared feeling; (b) shared doing; (c) shared saying; and (e) shared things. Thereby, the concept of school planning contained in the entrepreneurial school cultures within the artifacts layer on the verbal/conceptual dimension should be shared more among the school members by means of shared feeling, shared doing, shared saying and shared 
things. Through the communication, the matters that were related to the entrepreneurial characters would perfectly form the basic assumptions in the entrepreneurship.

The study supported the theory of Ciputra (2008, p. 53) that explained that based on his life experience the 3L path (lahir (born), lingkungan (environment) and latihan (practice) might be used for shaping an entrepreneur. In the study the researcher also found many efforts done by the VHS in pursuing the formation of entrepreneurship by means of Lingkungan (Environment) and Latihan (Practice). However, the Lahir (Born) aspect was not covered in the study. Ciputra (2008, p. 53) also explained if someone had gone through the 3-L path, then he or she would be a successful entrepreneur. On the contrary, the someone had not gone through the 3-L path then he or she would be quite difficult in pursuing the dream of being a successful entrepreneur. A successful entrepreneur might not rely on a series of unpredictable coinci-dence. Thereby, the vocational high school graduates that would have been more prepared for entrepreneurial efforts were the ones that had been trained by the VHS through the environment that contained the entrepreneurial characters and that came from the entrepreneurial families.

The results of the study also supported the theory of Ciputra $(2008$, p. 85$)$ which explained that the concept of entrepreneurship education that had been in accordance with the implementation for the VHS. The same entrepreneurship education was similarly implemented in the Ciputra University and the core of the education was that the entrepreneurship had been a concept wider than the mere concept of business. Ciputra also stated that his concept was a social entrepreneurship that emphasized on: (1) formation of paradigm; (2) attitude; and (3) certain life skills which eventually generated the capability of creating opportunities, innovations and calculated risk-taking.

The Entrepreneurial Character Education-School Cultures found in the study had been in line with the concept of entrepreneurial education implementation in the VHS provided by the Center of Curriculum, Institutin of Research and Development, the Ministry of National Education. The concept of entrepreneurial education for the VHS provided by the Center of Curriculum would be implemented by: (a) manifesting the entrepreneurial education into all subjects, teaching materials, extracurricular activities and even self-development; (b) developing the educational curriculum that provided the concents of entrepreneurial education for raising the awareness toward the entrepreneurship and for growing the entrepreneurial characters and/or skills; and (c) developing the entrepreneurial cultures within the school environment by means of school cultures that should be supported by the local contents (Usman, 2010, p. 6).

\section{CONCLUSIONS}

Based on the results of the study toward the entrepreneurial character education by means of school cultures (the Entrepreneurial Character Education-School Cultures) in the 2 Depok Public Vocational High School and 2 Pengasih Public Vocational High School, the researcher would like to draw the following conclusions.

First, the entrepreneurial character education in the 2 Depok Public Vocational High School and the 2 Pengasih Public Vocational High School was implemented by means of school cultures and the implementation of the entrepreneurial character education consisted of three dimensions namely: (a) verbal/conceptual dimension; (b) behavioral dimension; and (c) physical/material dimension. Then, the Entrepreneurial Character Education-School Cultures in the verbal/conceptual dimension was performed through: (a) the schools' vision and mission in the entrepreneurship; (b) the 2009 Curriculum and the 2013 Curriculum; (c) the schools' organizational structure; (d) the history and the figures of entrepreneurial success in the schools; and (e) the language spoken in the schools.

Second, the Entrepreneurial Character Education-School Cultures in the behavioral dimension was implemented by means of: (a) entrepreneurial teaching-learning activities; (b) routine entrepreneurial habits/activities; (c) entrepreneurial rules, awards and punishments; (d) psychological and social supports toward the entrepreneurial activities; and (e) interactions with the parents and the society in the entrepeneurship.

Third, the Entrepreneurial Character Education-School Cultures in the physical/material dimension was implemented by means 
of: (a) entrepreneurial tools and facilities; (b) forms and layouts of buildings that were used for the entrepreneurial activities; (c) entrepreneurial mottos and decorations; and (d) practical uniforms in the schools.

Fourth, there were 18 entrepreneurial characters of the Entrepreneurial Character Education-School Cultures in the study. Then, there were 17 dominant entrepreneurial characters within the Entrepreneurial Character Education-School Cultures namely: (a) creative; (b) vision to the future; (c) innovative; (d) realistical decision-taking; (e) independent; (f) honest; (g) responsible; (h) committed; (i) encouraged risk-taking; (j) never giving up; (k) curious; (l) communicative; (m) cooperative; (n) hardworking; (o) showing leadership; (p) disciplined; and (q) action oriented.

The suggestions that may be provided for this research are as follow:

First, the Directory of Vocational High School Coaching should support the efforts of pursuing the entrepreneurial character education by means of school cultures. The steps that should be taken are performing socialization and publishing the manual of entrepreneurial character education in th vocational high schools in order to accompany the development of entrepreneurial educaton that had been done by the Center of Curriculum and Book Publishing, the Ministry of National Education.

Second, the principals should actively socialize and evaluate the entrepreneurial character education by means of school culture toward all of the school members, especially in the artifacts layer on the behavioral dimension. The socialization and the evaluation should be accompanied by the benefits of human resources as having been implied in the entrepreneurial cultures lied in the artifacts layer on the physical/material dimension.

Third, all of the teachers should be active facilitators and evaluators toward the activities of entrepreneurial character education by means of school cultures by using the role modelling, the learning, the empowering, the habituating, the strengthening and the evaluating strategies.

Fourth, the school employees should totally support the efforts of entrepreneurial character education by means of school culture with their role as the teachers' partners in each of the entrepreneurial education activities by means of school cultures.

Fifth, the students should be ready as the executors of entrepreneurial character education by means of school cultures under the teachers' guidance.

Sixth, the business/the industrial domain (Dunia Usaha/Dunia Industri or also known as $D U D I)$ should optimize the partnership with the VHS through the industrial working practice, the entrepreneurial education and training, the student company coaching, the teaching factory development, the unit of job implementation and alike.

\section{REFERENCES}

Akbar, A. I. (2009). Pendidikan berbasis hard skill dan soft skill. Retrieved February 15, 2012, from http://mkadministrasinegara.blogspot.com/2009/0 6/pendidikan-berbasis-hard-skill-dansoft.html.

Anonim. (2003). Studi efektifitas pemberian beasiswa bakat dan prestasi, pengembangan kultur sekolah dan analisis studi kebijakan. Yogyakarta: Program Pascasarjana UNY.

Berkowitz, M. W., \& Bier, M. C. (2005). What works in character education: A research-driven guide for educators. Washington: Marillac Hal. Retrieved from http://www.character.org/uploads/PDFs/ White_Papers/White_Paper_What_Wor ks_Practitioner.pdf

Ciputra. (2008). Ciputra quantum leap: Entrepreneurship mengubah masa depan bangsa dan masa depan anda. Jakarta: PT. Elex Media Komputindo.

Depdiknas. (2003). Pedoman pengembangan kultur sekolah. Jakarta: Direktorat Pendidikan Menengah Umum, Dirjen Dikdasmen, Departemen Pendidikan Nasional.

Dharma, S. (2009). Bahan belajar fleksible: kewirausahaan. Jakarta: Direktorat Tenaga Kependidikan Dirjen PMPTK.

Elkind, D. H., \& Sweet, F. (2004). How to do character education. Retrieved January 11, 2012, from 
http://www.goodcharacter.com/ Article_4.html.

Goleman, D. (2006). Kecerdasan emosional: Mengapa EI lebih penting dari IQ. Jakarta: Gramedia Pustaka Utama.

Hatch, M. J. (1993). The Dynamics of organizational culture. The Academy of Management Review, 18(4), 657-693. Retrieved from http://links.jstor.org/sici?sici=0363$7425 \% 28199310 \% 2918 \% 3 \mathrm{~A} 4$ $\% 3 \mathrm{C} 657 \% 3 \mathrm{ATDOOC}$ \%3E2.0.CO\%3B2-E

Kotter, J. P., \& Hesket, J. L. (1997). Corporate culture and perfomance. (B. Molan, Trans.). Jakarta: PT. Prehhallindo.

Nuh, M. (2010). Desain induk pendidikan karakter kementerian pendidikan nasional. Jakarta: Kementrian Pendidikan Nasional.

Presiden Republik Indonesia. Instruksi Presiden Republik Indonesia Nomor 4 Tahun 1995 tentang Gerakan Nasional Memasyarakatkan dan Membudayakan Kewirausahaan (1995).

Prosser, C. A., \& Quigley, T. H. (1950). Vocational education in a democracy. Chicago: American Technical Society.

Ramly, M., Utomo, E., Sutjipto, Hasan, S. H., Wahab, A. A., Mulyana, Y., ... Ismail,
A. B. (2010). Pengembangan pendidikan budaya dan karakter bangsa. Jakarta: Pusat Kurikulum, Balitbang, Kemendiknas.

Samani, M., \& Hariyanto. (2011). Konsep dan model pendidikan karakter. Bandung: Rosdakarya.

Sathe, V. (1985). Culture and related corporate reality. Homewood: Ricard D Irwin.

Schein, E. H. (2004). Organizational culture and leadership (4th ed.). San Fransisco: Josey-Bass.

Sobirin, A. (2009). Budaya organisasi. Yogyakarta: UPP STIM YKPN.

Stolp, S. (1994). Leadership for school culture. Retrieved January 8, 2011, from http://eric.uoregon.edu/publications/dige sts/digest091. html

Stolp, S., \& Smith, S. C. (1995). Transforming school culture: stories, symbols, values \& the leader's role. (U. of Oregon, Ed.). Oregon.

Usman, H. (Ed.). (2010). Pengembangan pendidikan kewirausahaan. Jakarta: Pusat Kurikulum, Badan Penelitian dan Pengembangan, Kementerian Pendidikan Nasional.

Want, J. (2007). Corporate culture. New York: St. Martin's Press. 